\title{
Use of Lyophilized Porcine Skin to the Oral Wound
}

\author{
- Clinical Application and Experimental Evaluation as a Temporary \\ Dressing Material-
}

\author{
Toshihiko FujIWARA, Kunio IKemURA and Yasutaka Kouno \\ Department of Dentistry and Oral Surgery, Hospital, University of Occupational and \\ Environmental Health, Japan. Kitakyushu 807, Japan
}

\begin{abstract}
In order to cover the defect of the oral mucosa temporarily, we used lyophilized porcine skin (LPS) in 10 cases. The use of LPS seemed to be effective from the following points of view; alleviation of postoperative pain and as a protection against exogenous irritants. A fixation method, that is, a continuous locked suture, was devised technically to prevent the LPS from tearing by suturing. With this simple method, the patient maintained good oral hygiene and had only a slight discomfort. Histological examination using Japanese white rabbits showed no apparent difference in wound healing between this method and interrupted suture with tie-over compression. Re-epithelialization of the wound in the non-dressed (control) group was recognized earlier than that in the LPS-covered group.
\end{abstract}

Key words: lyophilized porcine skin, oral wound dressing, continuous locked suture.

(Received 11 November 1983)

\section{Introduction}

A relatively large and superficial defect of the oral mucosa often occurs following excision of various lesions, trauma, preprosthetic surgery and periodontal operation. In such a defect, primary closure is difficult. It has been covered with an autograft, for example, the skin, buccal, labial and palatal mucosas. However, the usage of the autograft necessitates another operation in the donor site and the amount of available tissue is limited. Therefore, lyophilized porcine skin (LPS) has been used recently as a temporary dressing material of the oral wound with good results.

This paper describes results of 10 clinical cases with application of LPS and a technical device in fixation of the LPS. Furthermore, in order to compare the healing process of a LPS-covered wound with that of a non-dressed wound, the results obtained from histological examinations using Japanese white rabbits are discussed.

\section{Clinical Cases}

Clinical cases are summarized in Table 1. Six of 10 cases were lekoplakia of the gingiva or buccal mucosa and the rest were composed of miscellaneous diseases. Seven 
cases had underlying bone tissue in the applied region. The size of the defect ranged from about 0.5 by $3.0 \mathrm{~cm}$ to 5.0 by $4.0 \mathrm{~cm}$. In seven cases, fixation and compression of the LPS were performed by an interrupted suture with a tie-over (Fig. 1) or a denture (plate) as a stent. In these cases, the edge of LPS was inclined to tear by suturing. Therefore, a continuous locked suture was tried in three cases (Fig. 2). The postoperative course is demonstrated in Table 1. In all cases, there were neither infection nor bleeding after the operation. A limitation of the mandibular movement, which is often recognized postoperatively in surgery of the buccal mucosa, did not occur (Fig. 3).

Table 1. Results of clinical cases

\begin{tabular}{|c|c|c|c|c|c|c|c|c|}
\hline $\begin{array}{l}\text { Case } \\
\text { No. }\end{array}$ & Age & Sex & $\begin{array}{l}\text { Diagnosis } \\
\text { (location) }\end{array}$ & $\begin{array}{l}\text { Fixation and } \\
\text { Compression }\end{array}$ & $\begin{array}{l}\text { Postope. } \\
\text { pain** }\end{array}$ & $\begin{array}{l}\text { Period for re- } \\
\text { epithelialization } \\
\text { (ca. days) }\end{array}$ & $\begin{array}{l}\text { Apparent } \\
\text { scar } \\
\text { formation }\end{array}$ & $\begin{array}{l}\text { Clinical } \\
\text { effec- } \\
\text { tiveness }\end{array}$ \\
\hline 1 & 62 & $\mathrm{M}$ & $\begin{array}{l}\text { Leukoplakia } \\
\text { (gingiva) }\end{array}$ & $\mathrm{I}+\mathrm{D}$ & - & 16 & - & A \\
\hline 2 & 66 & $M$ & $\begin{array}{l}\text { Leukoplakia } \\
\text { (gingiva) }\end{array}$ & $\mathrm{I}+\mathrm{T}$ & - & 30 & - & A \\
\hline 3 & 45 & $\mathrm{M}$ & $\begin{array}{l}\text { Leukoplakia } \\
\text { (cheek) }\end{array}$ & $\mathrm{I}+\mathrm{T}$ & \pm & 40 & - & B \\
\hline 4 & 85 & $F$ & $\begin{array}{l}\text { Leukoplakia } \\
\text { (gingiva) }\end{array}$ & $\mathrm{I}+\mathrm{T}$ & + & 14 & - & B \\
\hline 5 & 57 & $\mathrm{~F}$ & $\begin{array}{l}\text { Leukoplakia } \\
\text { (gingiva) }\end{array}$ & $C+D$ & - & 28 & - & A \\
\hline 6 & 58 & $\mathrm{M}$ & $\begin{array}{l}\text { Leukoplakia } \\
\text { (gingiva) }\end{array}$ & $\mathrm{C}+\mathrm{D}$ & - & 36 & - & A \\
\hline 7 & 79 & $\mathrm{~F}$ & $\begin{array}{l}\text { Carcinoma } \\
\text { (cheek) }\end{array}$ & $\mathrm{I}+\mathrm{T}$ & + & 48 & \pm & C \\
\hline 8 & 68 & $\mathrm{M}$ & $\begin{array}{l}\text { Oro-antral } \\
\text { fistula }\end{array}$ & $I+P$ & - & 39 & - & A \\
\hline 9 & 18 & $\mathrm{M}$ & $\begin{array}{l}\text { Trauma } \\
\text { (gingiva) }\end{array}$ & $\mathrm{I}+\mathrm{P}$ & - & 39 & - & A \\
\hline 10 & 36 & $\mathrm{M}$ & $\begin{array}{l}\text { Donor site } \\
\text { for conjunc- } \\
\text { tivoplasty } \\
\text { (lower lip) }\end{array}$ & $\mathrm{C}$ & -- & 28 & - & A \\
\hline
\end{tabular}

* I : Interrupted suture

$\mathrm{D}:$ Denture as a stent

- : Neither spontaneous pain nor discomfort

P : Compression plate

\pm : Discomfort without pain

$\mathrm{T}$ : Tie-over compression

+ Slight spontancous pain

$\mathrm{C}:$ Continuous locked suture

++ : Painful

*** Clinical effectiveness was evaluated on the basis of postoperative pain and apparent scar formation.

A : Negative in both

B: Positive in one or the other

C: Positive in both 


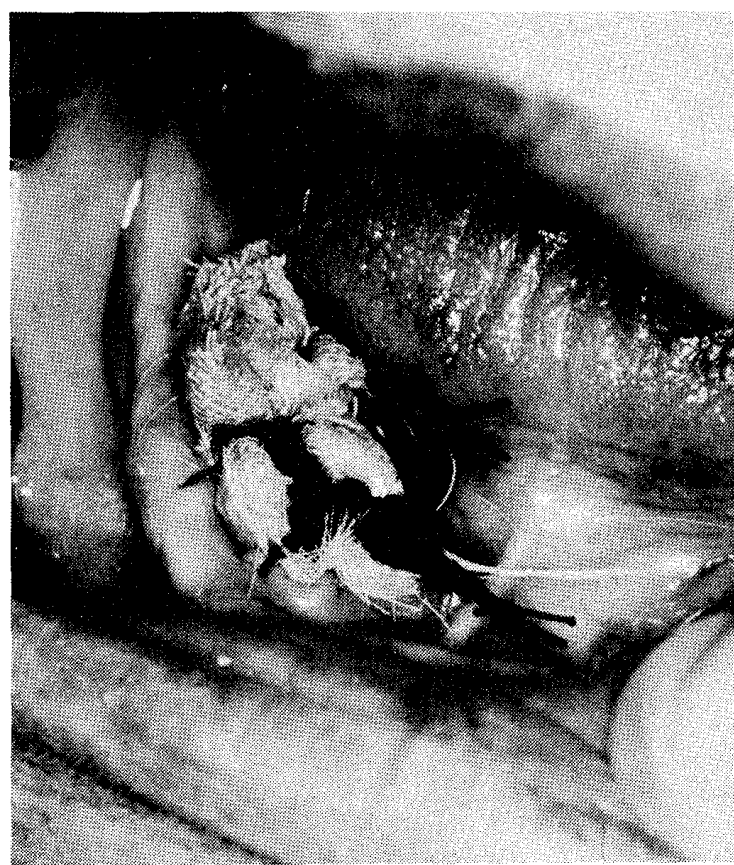

Fig. 1. LPS was compressed to the wound using a tie-over (Case 4).

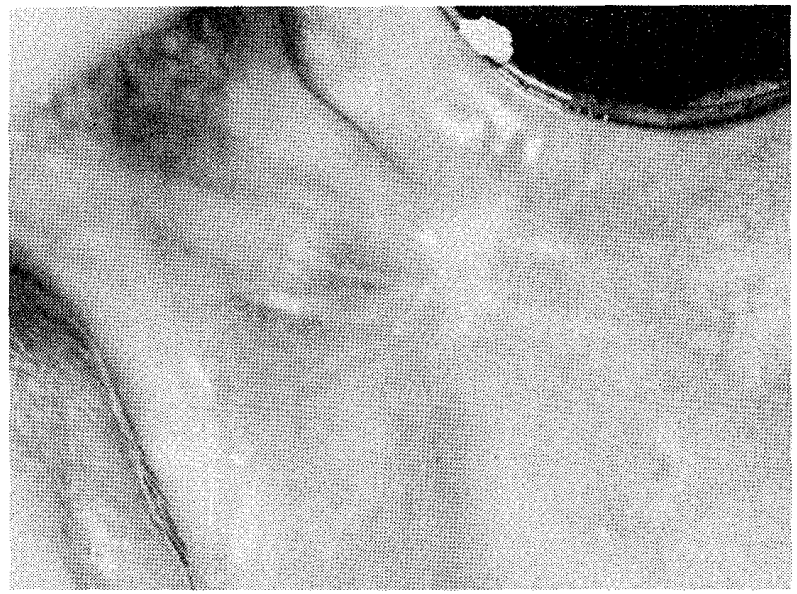

Fig. 3. Findings after the tumorectomy of the buccal mucosa (postoperative period-48 days). Limitation of the mandibular movement which was often recognized in such operations did not occur, though a little radial scar formation was seen (Case 7).

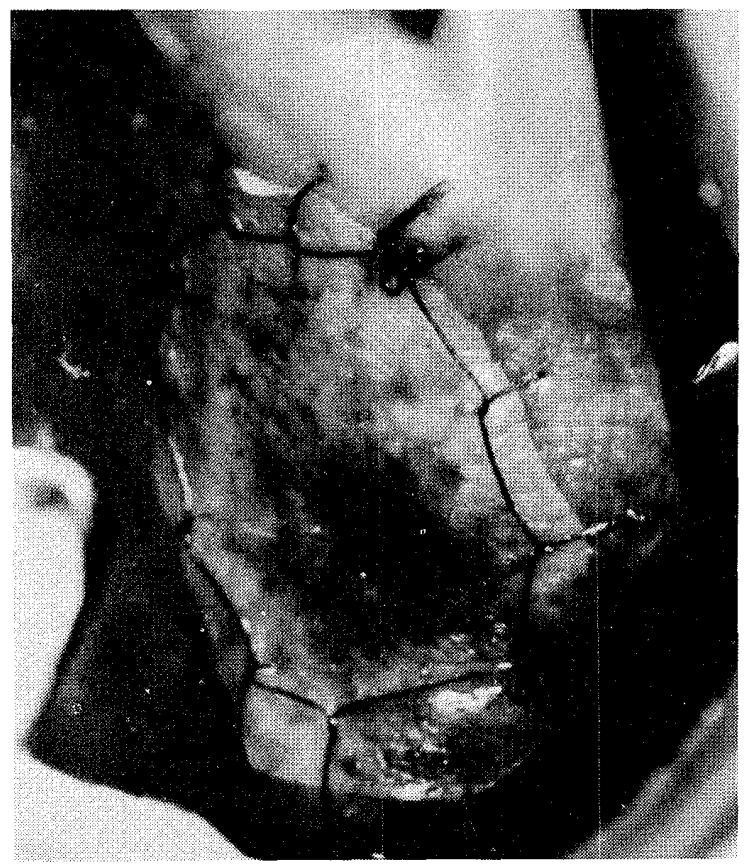

Fig. 2. LPS was fixed by a continuous locked suture and compressed by denture (Case 5).

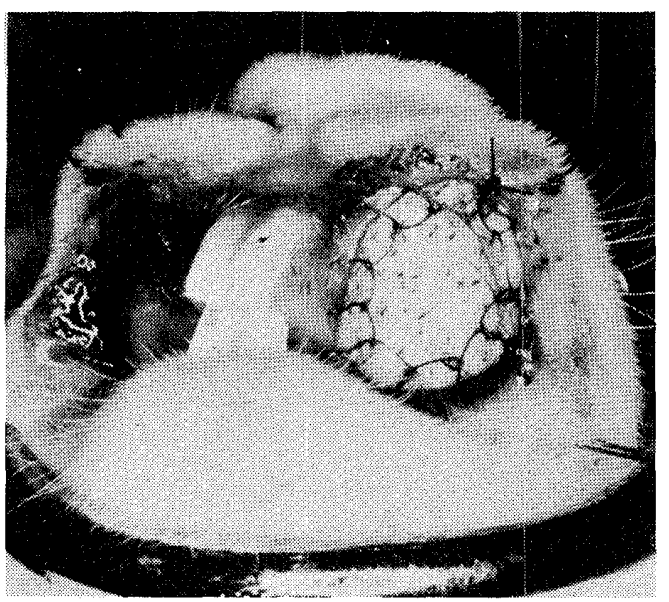

Fig. 4. A circular wound, about $1 \mathrm{~cm}$ in diameter, was made on both upper labial mucosa. The left wound was covered with LPS by a continuous locked suture. 


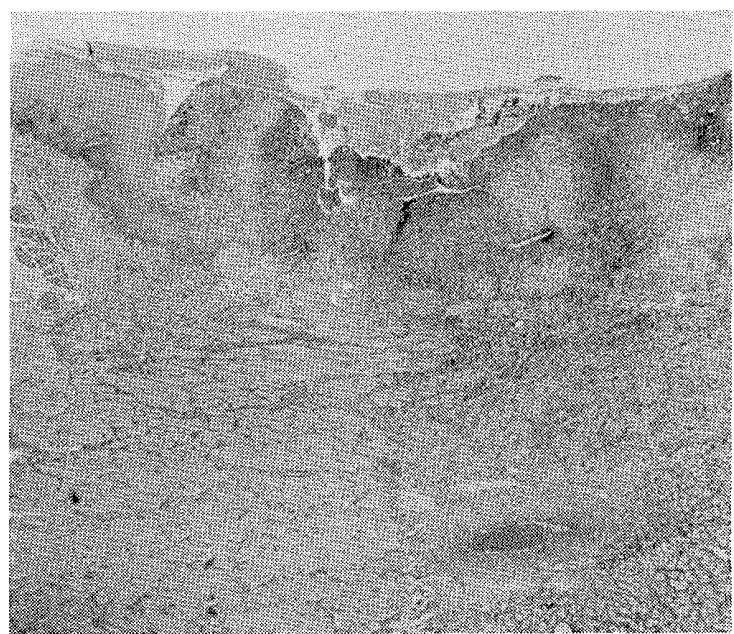

Fig. 5. The epithelium of the wound margin at three days postoperatively began to regenerate underneath the fibrinoid exudates. (Hematoxylin and eosin stain. Magnification $\times 40)$

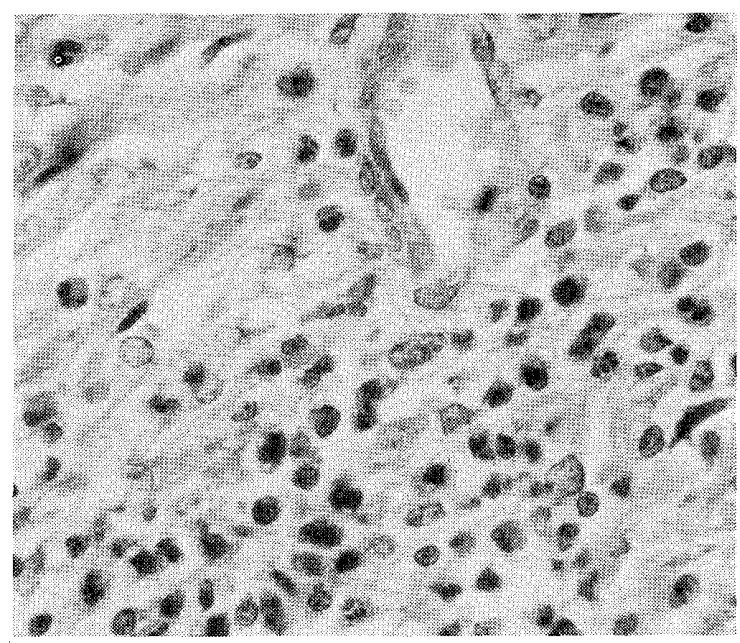

Fig. 7. Eosinophils predominate in the subepithelial connective tissue. (Hematoxylin and eosin stain. Magnification $\times 1000)$.

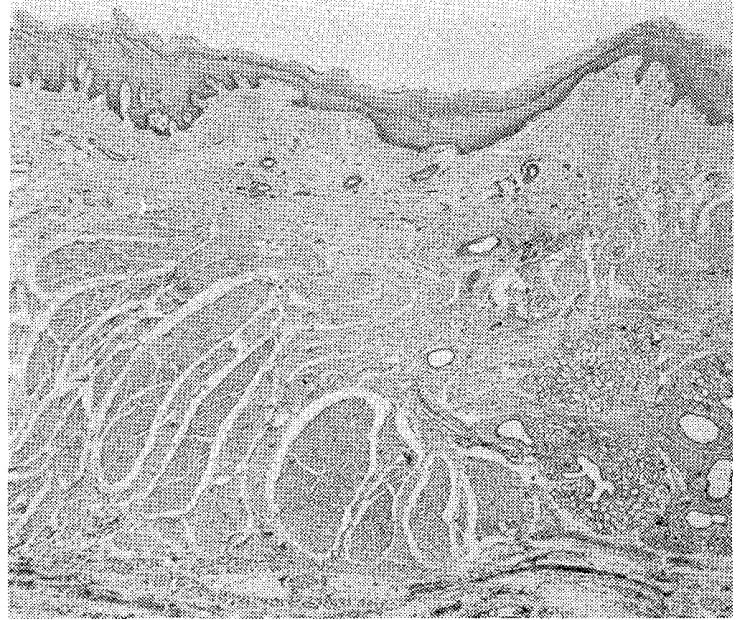

Fig. 6. At 21 days after the operation, the continuity of the epithelium was restored and muscles began to regenerate in the granulation tissue. (Hematoxylin and eosin stain. Magnification $\times 40$ ).

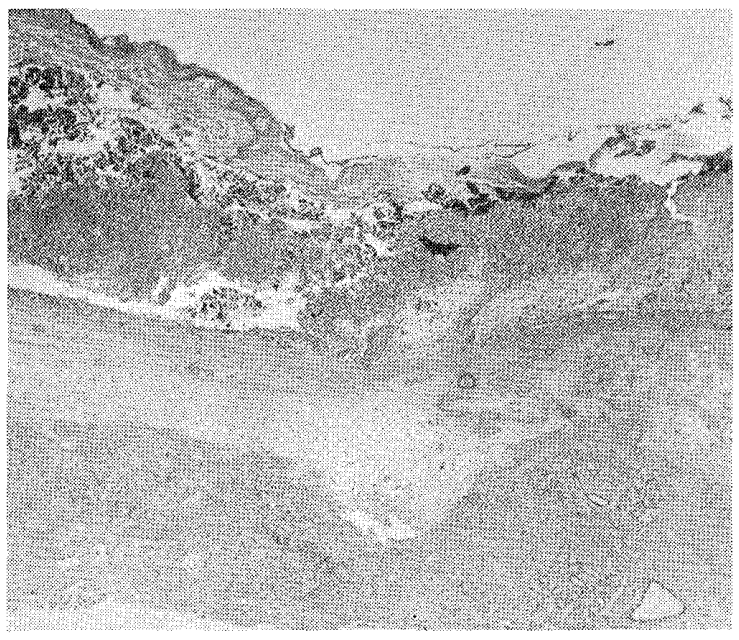

Fig. 8. An elastin-fibrin bonding connected the LPS with the wound at three days after the operation. (Hematoxylin and eosin stain. Magnification $\times 40$ ).

\section{Experimental Study}

1. Materials and methods

Twenty Japanese white rabbits, wighing about $2 \mathrm{~kg}$, were used in this study. A circular wound, approximately $1 \mathrm{~cm}$ in diameter, was made on the right and left upper labial mucosa in each animal. The right wound (control) was allowed to heal by secondary epithelialization. The left wound was covered with LPS, using two different fixa- 
tion methods. The first method was an interrupted suture with a tie-over compression and the second was a continuous locked suture without compression (Fig. 4). Each method was performed on 10 animals. After the macroscopic observation at 1, 3, 7, 14, 21 and 28 days after the operation, animals were sacrificed and specimens were taken. They were then fixed in $10 \%$ formalin solution and prepared for paraffin sections.

\section{Results}

On the first day, the control wound was covered with a mass of exudates and coagula accompanying severe infiltration of the inflammatory cells. These findings were seen on the first, third and seventh postoperative days. On the postoperative third day, the epithelium of the wound margin began to regenerate underneath the inflammatory fibrinoid exudates (Fig. 5). At 14 days after the operation, re-epithelialization was almost completed except for the center of the wound, and infiltration of the inflammatory cells significantly decreased. At 21 days postoperatively, the wound was totally regenerated and the color was identical with that of the non-operated area. In this stage, regenerated striated muscles were seen in the connective tissue (Fig. 6). At 28 days after the operation, the wound was smooth and demonstrated satisfactory histologic features of healing. On the other hand, the wound covered with LPS showed a slower healing, that is, approximately one week later than the control wound. Compared with the control group, the LPS-covered wound showed severe infiltration of the inflammatory cells, most of which were eosinophils (Fig. 7). However, this finding was not prevalent at 21 days. The fibrinoid exudates closely connected the wound and the LPS, which is a so-called "elastin-fibrin bond" (Fig. 8) (Burleson \& Eiseman, 1972). As the regeneration of the epithelium proceeded, this bonding was lost and the LPS gradually became detached from the wound. Regeneration of the epithelium and the detachment of the LPS occured simultaneously.

\section{Discussion}

To cover a relatively large and superficial defect of the oral mucosa, various kinds of autografts have been used, but their main disadvantages are the necessity of another operation in the donor site and the limited amount of tissue available. Our clinical experiences indicated that LPS was effective from the following points of view; alleviating postoperative pain and protection from exogenous irritants. Elliot \& Hoehn (1973) stated that biological dressing alleviated postoperative pain, presumably by covering the sensory nerve ending and restoring a near-normal tissue environment. Two cases (Case 4 and 7) of our 10 showed slight postoperative pain. In Case 4, the LPS was applied to the immovable mucosa using a tie-over compression. In this case, tight compression might evoke pain. In Case 7 , the wound was so deep as to reach the muscle layer. 
For the fixation of the LPS in the recipient site, an interrupted suture was used in most cases. This suturing method, however, often induced tearing of the LPS. Therefore, a continuous locked suture was tried in three cases (Case 5, 6 and 10) with good results. With this suturing method, the tearing of the LPS could be avoided and the LPS was kept in contact with the oral mucosa without a tie-over compression or a stent (Case 10). Moreover, this method provides the following advantages: Operative procedure is easy. Good oral hygiene can be preserved and the patient has less discomfort postoperatively. In addition, experimental study revealed that the wound compressed by a tie-over had an uneven and ragged margin. However, there was no difference in the period of wound healing between the tie-over group and the non-compressive group.

Friedman (1974) reported that another benefit of using LPS was prevention of excessive granulation tissue formation. Kasper \& Laskin (1983) stated that porcine skin, autogenous split-thickness skin and autogenous full-thickness palatal grafts all limited granulation tissue formation and thereby reduced the wound contraction in the oral cavity. However, no excessive granulation was seen in our control group with a raw surface. Also there was no apparent wound contraction. Histologically, it seemed that the raw surface of the control wound did not show more fibrosis than other groups. But, further investigation is necessary to determine whether the wound covered with LPS shows less contraction than the control wound, because the extent and depth of the wound appear to be important factors which contribute to the wound contraction.

The period of re-epithelialization under the application of LPS is controversial. Imai et al. (1977a, b) reported that coverage of a burn wound with LPS accelerated the re-epithelialization of the wound. Kondo et al. (1980) also reported the same effect in the oral wound. According to Kaneda et al. (1981), neither retardation nor acceleration of oral wound healing was seen. Our clinical cases did not give significant information about it. Varying from these opinions, retardation of wound healing was observed in our experimental study.

Kasai et al. (1977) revealed antigenicity of LPS extract in rabbits. In our experimental study, eosinophils predominated in the subepithelial layer until the 14th day postoperatively. This may suggest antigenicity of LPS and retardation of the wound healing might be caused by it. However, as Friedman (1974) stated, no additional application of LPS was needed in the oral application. Therefore, it seemed that antigenicity of LPS had little significance in the oral wound.

\section{Conclusion}

(1) The clinical benefits of the application of LPS to the oral wound were alleviating postoperative pain and protection from exogenous irritants.

(2) A continuous locked suture prevented the LPS from tearing by suturing and seemed to be efficacious in maintaining good oral hygiene and causing only slight discomfort to 
the patient.

(3) In our experiment, the control wound healed approximately one week earlier than the wound covered with LPS.

\section{References}

Burleson, R. \& Eiseman, B. (1972): Nature of bond between partial-thickness skin and wound granulations. Surgery, $72: 315-322$.

Elliot, R. A. \& Hoehn, J. G. (1973): Use of commercial porcine skin for wound dressings. Plast. Reconstr. Surg., 52: 401-405.

Friedman, E. (1974) : A preliminary report on pigskin grafts in oral surgery. Int. J. Oral Surg., $3: 269$.

Imai, S., Gibo, M., Nabeshima, K. et al. (1976a): The use of lyophilized porcine skin (ASK-M) in burns. J. J. Burn Inj., 2: 38-49. (in Japanese)

Imai, S., Gibo, M., Nabeshima, K. et al. (1976b) : The use of lyophilized porcine skin (ASK-M) in donor site. J. J. Burn Inj., 2: 50-55. (in Japanese)

Kaneda, T., Chujyo, A., Torii, S. et al. (1981): The clinical use of LPS (lyophilized porcine skin) as a temporary biological dressing in oral surgery. Jpn. J. Oral Surg., 27: 132-140. (in Japanese)

Kasai, H., Hosono, J. \& Iwasaki, M. (1977) : Studies on antigenicity of lyophilized porcine skin (LPS). 1. Immune responses of rabbits immunized with LPS extract. Pharmacometrics, 14:775781. (in Japanese)

Kaspar, D. W. \& Laskin, D. M. (1983) : The effect of porcine skin and autogenous epithelial grafts on the contraction of experimental oral wounds. J. Oral Maxillofac. Surg., 41: 143-152.

Kondo, T., Kikuta, T., Kinebuchi, T. et al. (1980) : Clinical application of lyophilized porcine skin in the oral region. Jpn. J. Oral Surg., 26: 1128-1134. (in Japanese) 


\section{凍結乾燥豚皮の口腔内臨床応用 10 例と実験的検討}

藤原 利彦・池村 邦男・河野 泰孝

産業医科大学病院歯科口腔外科

要旨：口腔外科臨木において，しばしば遭遇する比較的大きな粘膜欠損に対し，暫間被覆材とし て凍結乾燥豚皮 (LPS) を応用した 10 例を示した。いずれの症例も良好な治療経過をたど り,特に術後疼痛の緩利1, 食片なよ゙外来刺激に対する保護包带としての有用性が評価された。 また，脆弱なLPSの縫合には連続縫合を工坑した。この方法は従来の tie-over 法に比べ, 口腔衛生状態が改善され，患者の不快感も減少した。動物実験は日本白色家鬼を用い，両 側煩粘膜に径約 $1 \mathrm{~cm}$ の形創を作り，右側を対照とした，左側は結節縫合に tie-overを 加えた群と連続縫合のみの 2 群に分けてLPS を固定した。両群の治療像に差はみられな かった。なお，対照群とLPS 被覆群の上皮化までの期間の比較では対照群がより早い上 皮化を示した。 